Mulesa 0., Snytyuk V., Nazarov V.

\title{
RESEARCH OF INFORMATION-ANALYTICAL ASPECTS FOR OPTIMIZATION OF THE HEALTH CARE INSTITUTIONS
}

Сфера охорони здоров'я є пріоритетною в державному вимірі. Від ефективності функиіонування мережі закладів охорони здоров'я залежить доступність та якість медичних послуг. Оптимізація діяльності закладів охорони здоров'я з метою задоволення потреб населення в медичних послугах $є$ важливою задачею. Розробка і впровадження інформаційних технологій в процеси прийняття управлінських рішень при щьому дозволить підвищити їх ефективність.

Об'єктом дослідження є процеси інформаційно-аналітичного супроводу прийняття управлінських рішень щодо клієнтоорієнтованої оптимізацї діяльності закладів охорони здоров'я в умовах невизначеності. Такий супровід необхідний для забезпечення ефективного аналізу наявних даних, врахування ситуаційної та інформаційної невизначеності та формування на основі цього множини ефективних рішень. Особливістю даної проблеми є те, що при ї̈ вирішенні необхідно аналізувати та робити висновки на основі даних різної природи: як фактичних даних про діяльність закладів охорони здоров'я в різні періоди часу, результатів анкетних даних представників різних сочіальних груп, так і висновків експертів.

В ході дослідження використовувалися загальнонаукові методи, методи математичного моделювання, а також системний підхід. Для ефективного вирішення поставленої проблеми пропонується розглядати заклад охорони здоров'я як цілісну систему, яка характеризується внутрішніми зв'язками та впливом зовнішнього середовища.

В результаті проведеного дослідження вироблено алгоритм аналізу діяльності закладів охорони здоров'я, виконання якого дозволить розрахувати потреби в медичному персоналі в наступні періоди часу.

Систематизовано дані відповідно до іхх походження. Відмічено, що важливим джерелом даних $\epsilon$ результати експертних опитувань. Розроблено структурно-функціональну схему інформаційно-аналітичного супроводу особи, яка приймає рішення, в прощесі оптимізащї кадрового складу закладу охорони здоров'я. Розробка та впровадження інформаційно-аналітичного забезпечення для аналізу кадрової діяльності закладу охорони здоров'я дозволить підвищити ефективність відповідних управлінських рішень.

ключові слова: якісні медичні послуги, інформачійно-аналітичний супровід, медичні кадри, клієнтоорієнтована оптимізація.

Received date: 18.10 .2019

Accepted date: 05.11.2019

Published date: 30.12 .2019
Copyright (C) 2019, Mulesa O., Snytyuk V., Nazarov V. This is an open access article under the CC BY license (http://creativecommons.org/licenses/by/4.0)

\section{Introduction}

The continuous development of information technologies contributes to their implementation in various spheres of human activity in order to ensure the analysis of the necessary data and the acquisition of new knowledge. The health sector is a priority in the national dimension. The availability and quality of medical services depends on the effectiveness of the functioning of the network of health care institutions. An analysis of high-quality medical services on mortality rates in different countries showed that improving access to effective medical services significantly affects life expectancy in most European countries. A decrease in mortality in all countries by an average of $17 \%$ is revealed [1]. Thus, the optimization of the activities of health care institutions in order to meet the needs of the population in medical services is an urgent task. The development and implementation of information technology in the processes of managerial decision-making in this case will increase their effectiveness.
This study examines the problem of implementing informational and analytical support for managerial decisionmaking processes to optimize the personnel of health care institutions (HCI).

\section{The object of research and its technological audit}

The object of research is the processes of informational and analytical support for making managerial decisions on customer-oriented optimization of the activities of health care institutions in the face of uncertainty. Such support is necessary to ensure effective analysis of available data, taking into account situational and informational uncertainty [2] and the formation on the basis of this set of effective solutions.

The most important step in decision-making processes for optimizing the activities of health care institutions is the formalization of the tasks that arise and the streamlining of data. 


\section{The aim and objectives of research}

The aim of research is determination of the features of information and analytical support for the process of optimizing the HCI personnel composition.

To achieve this aim, it is necessary to complete the following objectives:

1. To analyze the measures necessary to optimize the HCI personnel.

2. To systematize the data obtained from various sources that are necessary to obtain new knowledge in the process of making appropriate management decisions.

3. To develop a structural-functional diagram of information and analytical support for the decision-maker in the process of optimizing the HCI personnel.

\section{Research of existing solutions of the problem}

According to the concept of the World Health Organization, it is necessary to ensure an approach in which everyone has access to safe, effective, timely, modern and highquality medical services [3]. To meet the needs of the population in medical care, it is necessary to provide an adequate number and level of training for medical and managerial personnel. Among the indicators that are studied in the research of this problem is the ratio of the number of posts of doctors and posts of nurses; the proportion of certified doctors, paramedics, health care organizers $[4,5]$.

Effective business management is associated with the need to implement the following tasks:

- optimization of the HCI structure;

- optimization of the interaction of various HCIs;

- raising the level of qualification of HCI personnel;

- increasing the level of information support for the

HCI management processes and the adoption of medi-

cal decisions in clinical practice;

- monitoring and evaluating the activities of the institution as a whole, structural units and personally each medical worker of the hospital.

In the course of the implementation of measures to analyze the HCI activities in order to optimize its activities in the personnel aspect, it is necessary to implement a sequence of steps [6] (Fig. 1).

The multi-stage process of analyzing the HCI activities, as well as the need for the consistent solution of a large number of tasks and handling large volumes of data of various natures, necessitates the use of special information technologies [7-9]. The development and use of relevant information and analytical support in the process of analyzing the HCI activities will make it possible to obtain timely and objective assessments of their activities, which, in turn, will become the basis for effective management decisions [10-13].

The analysis of scientific sources and the regulatory framework shows that at present the problem of optimizing the personnel of health care institutions is unsolved.
Promising is the development and implementation of special information and analytical support for data analysis and effective support of managerial decision-making processes. 
3. Dynamic series $(D s)$ and statistical data $(S t)$ regarding the values of the studied quantities in past periods of time [14].

4. Results of expert surveys $(E)$ - data sets containing information on the conclusions of experts on issues related to the problem under study [15].

5 . The results of the survey of potential consumers of medical services (Q) [16].

6. Results of voting on management decisions taken collectively $(V)$.

In the process of optimizing the HCI personnel, it is necessary to solve a number of problems to determine key indicators of the institution. Among them:

1. The task of assessing the volume of services that can be provided by HCI personnel within their working time [17].

It is necessary to build rule $\Theta$, with the help of which, based on the specified HCI characteristics, it would be possible to determine the allowable load on the personnel of the institution in the given form $N B$ :

$$
\Theta:(W, S, E) \rightarrow N B \text {. }
$$

2. The task of assessing the existing burden on the HCI personnel [17].

Build the rule $\Delta$, according to which, based on the information on HCI and statistical data on the services provided by the personnel of the institution for a certain period of time, it would be possible to determine the actual load on the personnel of the institution $(R B)$ :

$\Delta:(W, S, S t, E) \rightarrow R B$.
3. The task of forecasting future needs for medical services is the need to build a rule $\Omega$ to assess the level of demand for medical services $(D)$ :

$$
\Omega:(S, D s, S t, E, Q) \rightarrow D \text {. }
$$

4. The task of making managerial decisions on the HCI activities: to build a rule $\psi$ for the formation of set of effective decisions (ED) based on data obtained from the use of rules (1)-(3):

$$
\psi:(W, N B, R B, D, E, V) \rightarrow E D .
$$

Based on the set of EDs that have developed as a result of solving problem (4), the decision-maker can formulate a program for the process of optimizing the HCI personnel composition.

At the next stage of the study of the problem of optimizing the HCI personnel composition, it is advisable to develop models, methods and tools for information and analytical support of the decision-maker to perform such optimization. This support should be an effective analysis of the available data and the acquisition of new knowledge on their basis. As a result of such support at each stage, the decision maker should receive solutions to the tasks, and as a result, set of effective management decisions to optimize the HCI personnel.

Schematically, information and analytical support for the process of solving the problem of optimizing the HCI personnel composition can be represented as shown in Fig. 2.

The next steps are the development and implementation of information and analytical support for solving the tasks.

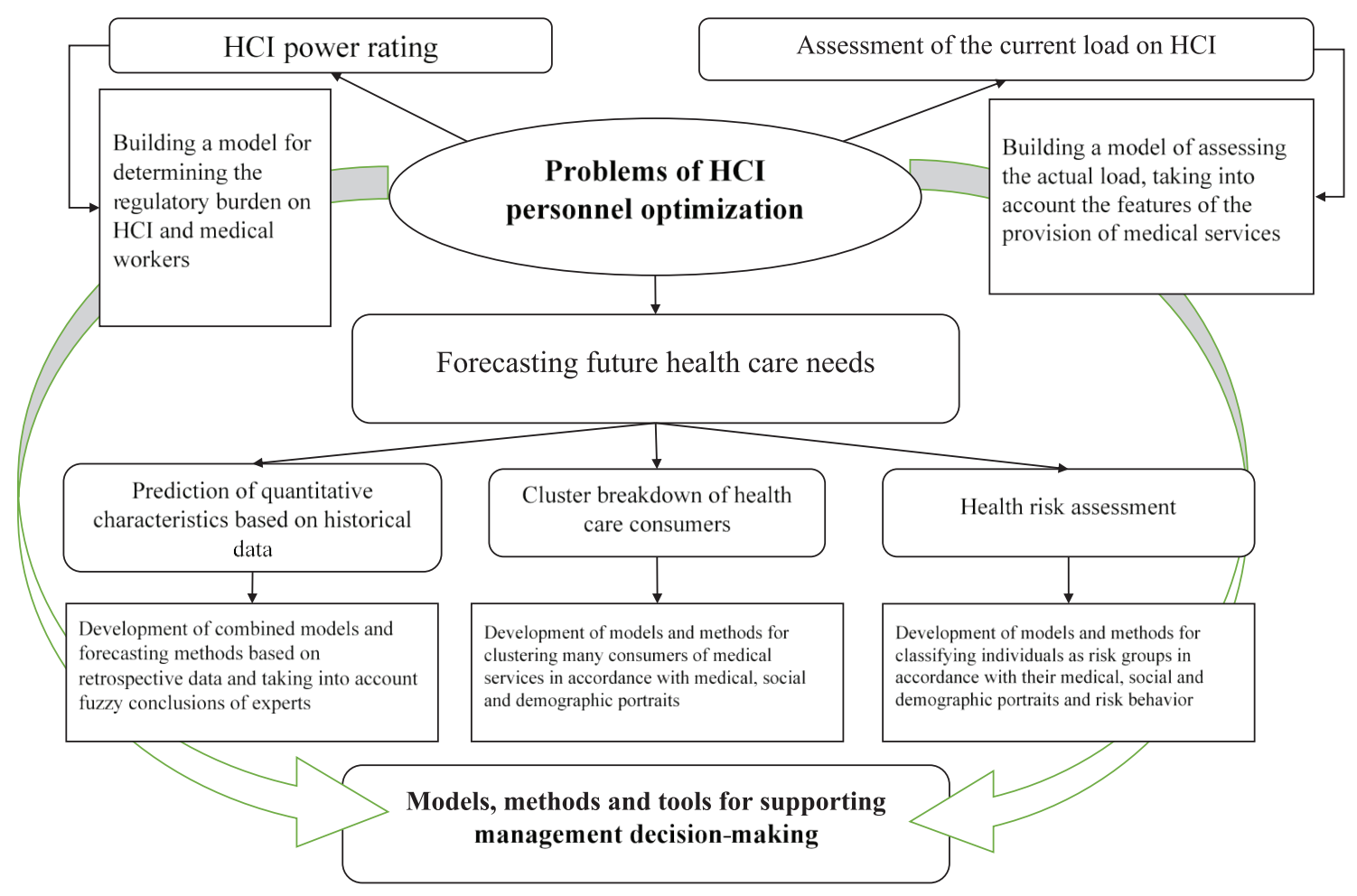

Fig. 2. Structural and functional diagram of information and analytical support in the process of optimizing the personnel of health care institutions (HCI) 


\section{SWOT analysis of research results}

Strengths. The problem of optimizing the personnel of the health care institution is analyzed. An algorithm for analyzing the HCI activities is determined, on the basis of which the main tasks that arise in this process are formulated. A structural and functional scheme of information and analytical support for a decision-maker in the process of optimizing the HCI personnel is developed. The application of the developed approach for information and advisory support of processes for optimizing the activities of the HCI personnel will increase the effectiveness of relevant management decisions.

Weaknesses. The main source of data is in solving the tasks of the conclusions of experts. Therefore, the important issue is the selection of a group of competent experts for conducting an expert survey.

Opportunities. The use of special information and analytical support in the process of making managerial decisions to optimize the HCI personnel will increase the efficiency of such institutions.

Threats. The implementation of some management decisions requires additional material and technical resources and time, therefore, it is important to make an effective forecast regarding the values of the studied numerical indicators in future time periods.

\section{Conclusions}

1. The analysis of the measures necessary for the optimization of the HCI personnel. Based on the regulations, an algorithm for analyzing the HCI activities is developed. The algorithm divides the process of analyzing the HCI activities into interrelated stages. The consistent implementation of these stages allows to calculate the actual needs for medical personnel and medical services both in a specific HCI and in a specific territory.

2. Systematization of data by the criterion of their origin. It is noted that the results of expert surveys are an important source of data.

3. A structural and functional scheme of information and analytical support for a decision-maker in the process of optimizing the HCI personnel system is developed. The decision-making process is divided into stages, within which it is necessary to analyze the data of the corresponding block. The solution of the tasks in a certain sequence will allow to calculate indicators characterizing the effectiveness of the HCI personnel. Thus, the development and implementation of information and analytical support for the analysis of HCI personnel activities will increase the effectiveness of relevant management decisions.

\section{References}

1. Lekhan, V. M., Slabkyi, H. O., Shevchenko, M. V. (2010). Stratehiia rozvytku systemy okhorony zdorovia: ukrainskyi vymir. Ukraina. Zdorovia natsii, 1, 5-23.

2. Zghurovskyi, M. Z., Pankratova, N. D. (2007). Osnovy systemnoho analizu. Kyiv: Vydavnycha hrupa BHV, 444.

3. Rukovodstvo po nacionalnoi politike $i$ strategii v oblasti kachestva: prakticheskii podkhod $k$ razrabotke politiki i strategii v celiakh povysheniia kachestva medicinskoi pomoschi (2018). Zheneva: Vsemirnaia organizaciia zdravookhraneniia. Available at: https://apps.who. int/iris/bitstream/handle/10665/278964/9789244565568-rus.pdf
4. Medvedovska, N. V., Diachuk, D. D. (2012). Stan zdorovia dorosloho naselennia Ukrainy, diialnist ta resursne zabezpechennia zakladiv okhorony zdorovia $\mathrm{v}$ rehionalnomu aspekti. Ukraina. Zdorovia natsii, 1, 30-39.

5. Detsyk, O. Z., Melnyk, R. M. (2018). Analiz bachennia medychnykh pratsivnykiv shchodo problem orhanizatsii pediatrychnoi paliatyvnoi dopomohy v Ukraini. Ekonomika i pravo okhorony zdorovia, 2 (8), 17-22.

6. Slabkyi, H. O., Lobas, V. M., Kachur, O. Yu., Znamenska, M. A., Parkhomenko, H. Ya., Hot, N. R. (2013). Orhanizatsiia diialnosti oblasnoi likarni v umovakh reformuvannia systemy medychnoi dopomohy naselenniu. Kyiv, 23

7. Teterych, N. V., Tereshchenko, L. V. (2016). Doslidzhennia suchasnykh problem informatyzatsii okhorony zdorovia ta farmatsii v Ukraini. Sotsialna farmatsiia: stan, problemy ta perspektyvy. Kharkiv, $76-77$.

8. Mathar, T. (2010). Managing Health(-Care Systems) Using Information Health Technologies. Health Care Analysis, 19 (2), 180-191. doi: http://doi.org/10.1007/s10728-010-0150-z

9. Valladolid, C. (2016). Meaningfulness and job satisfaction for health care technology workers. Pepperdine University, 41.

10. Kapoor, B., Kleinbart, M. (2012). Building an Integrated Patient Information System for a Healthcare Network. Journal of Cases on Information Technology, 14 (2), 27-41. doi: http:// doi.org/10.4018/jcit.2012040103

11. Banton, C. L. (2014). The impact of multiple master patient index records on the business performance of health care organizations: A qualitative grounded theory study. University of Phoenix.

12. Wiley, M. T. (2016). Ontology-Based Analysis of Online Healthcare Data. UC Riverside.

13. Pawlson, G. (2002). Information Technologies And The Health Care Workforce. Health Affairs, 21 (6), 266-266. doi: http:// doi.org/10.1377/hlthaff.21.6.266

14. Heche, F., Mulesa, O., Myroniuk, I., Vashkeba, M. (2015). Forecasting quantitative characteristics of officially registered HIVinfected persons in the region. Technology audit and production reserves, 4 (2 (24)), 34-39. doi: http://doi.org/10.15587/23128372.2015.47907

15. Myroniuk, I. S., Mulesa, O. Yu., Nikolko, M. V. (2016). Dosvid vykorystannia metodu ekspertnykh otsinok dlia vyznachennia okremykh vydiv vtrat produktyvnoho robochoho chasu medychnykh pratsivnykiv rehionalnykh pidrozdiliv sluzhby protydii VIL-infektsii/SNIDu. Ukraina. Zdorovia natsii, 4/1 (41), 164-171.

16. Mulesa, O., Snytyuk, V., Myronyuk, I. (2016). Forming the clusters of labour migrants by the degree of risk of hiv infection. Eastern-European Journal of Enterprise Technologies, 3 (4 (81)), 50-55. doi: http://doi.org/10.15587/1729-4061.2016.71203

17. Mulesa, O., Geche, F., Nazarov, V., Trombola, M. (2019). Development of models and algorithms for estimating the potential of personnel at health care institutions. Eastern-European Journal of Enterprise Technologies, 4 (2 (100)), 52-59. doi: http:// doi.org/10.15587/1729-4061.2019.174561

Mulesa Oksana, PhD, Associate Professor, Department of Cybernetics and Applied Mathematics, State Higher Educational Institution «Uzhgorod National University», Ukraine, ORCID: http:// orcid.org/0000-0002-6117-5846, e-mail: mulesa.oksana@gmail.com

Snytyuk Vitaliy, Doctor of Technical Sciences, Professor, Head of Department of Intellectual Technologies, Taras Shevchenko National University of Kyiv, Ukraine, ORCID: http://orcid.org/0000-00029954-8767, e-mail: snytyuk@gmail.com

Nazarov Volodymyr, Postgraduate Student, Department of Cybernetics and Applied Mathematics, State Higher Educational Institution «Uzhgorod National University», Ukraine, ORCID: http:// orcid.org/0000-0002-0906-7020,e-mail:vonaz2713@gmail.com 